\title{
Phylogeography and genetic diversity of the copepod family Cyclopidae (Crustacea: Cyclopoida) from freshwater ecosystems of Southeast Nigeria
}

Yijun $\mathrm{Ni}^{1+}$, Chike Chukwuenyem Ebido ${ }^{1+}$, Elijah Chibueze Odii ${ }^{2}$, Jinhui Wang ${ }^{1}$, Chinemerem Hodges Orakwelu ${ }^{2}$, Francis Chukwuemeka Abonyi ${ }^{2}$, Chinedu Innocent Ngene ${ }^{2}$, Joseph Onyekwere Okoro²,

Patience Obiageli Ubachukwu' ${ }^{2}$ Wei Hu${ }^{1}$ and Mingbo Yin ${ }^{1 *}$

\begin{abstract}
Background: Copepods are key components of aquatic ecosystems and can help regulate the global carbon cycle. Much attention has been paid to the species diversity of copepods worldwide, but the phylogeography and genetic diversity of copepods in Nigeria is unexplored.

Results: Using a mitochondrial cytochrome c oxidase subunit I marker, we preformed phylogenetic and phylogeographic analyses for Cyclopidae copepods in Southeast Nigeria. A high species diversity of Cyclopidae in Nigeria: 5 species of Tropocyclops, 5 species of Mesocyclops and 2 species of Thermocyclops from Cyclopidae were identified in 15 populations. Moreover, we detected 18 unique haplotypes, which fell into two distinct clades. Pairwise genetic distances (uncorrected p-distances) among the species of Cyclopidae ranged from 0.05 to 0.257 . Several species co-existed in the same lake, and some haplotypes were shared among different geographic populations, suggesting a dispersal of Cyclopidae in our sampling region. Finally, we found that the population genetic diversity for each species of Cyclopidae was low in Nigeria.

Conclusions: Our findings explored the species diversity and distribution of copepods within the family Cyclopidae for 15 Nigerian freshwater ecosystems: a high species diversity of Cyclopidae copepods was detected over a small geographic sampling range. Results from this study contribute to a better understanding of copepod diversity of Nigerian freshwater ecosystems.
\end{abstract}

Keywords: Cyclopidae, Species diversity, COI, Nigeria

\section{Background}

Copepods are one of the most taxonomically diverse groups of crustaceans, containing approximately 14,000 described species globally [1]. Copepods can be found in most kinds of aquatic habitats because of their remarkable

\footnotetext{
* Correspondence: yinm@fudan.edu.cn

${ }^{\dagger}$ Yijun Ni and Chike Chukwuenyem Ebido contributed equally to this work. 'MOE Key Laboratory for Biodiversity Science and Ecological Engineering, School of Life Science, Fudan University, Songhu Road 2005, Shanghai, China Full list of author information is available at the end of the article
}

evolutionary adaptability $[1,2]$. They are key components in aquatic ecosystems, playing an important role in food webs $[3,4]$ and living as endo- or ectoparasites associated with aquatic animals $[2,5,6]$. Many previous studies have shown that copepods are sensitive to climate change [7, 8 ], because the range of copepods could track the rate of climate change [7]. Copepods can also help regulate the global carbon cycle $[9,10]$, and they can be used as indicators to natural and anthropogenic environmental stressors by tracing their responses to the elevation of atmospheric

(c) The Author(s). 2020 Open Access This article is licensed under a Creative Commons Attribution 4.0 International License, which permits use, sharing, adaptation, distribution and reproduction in any medium or format, as long as you give appropriate credit to the original author(s) and the source, provide a link to the Creative Commons licence, and indicate if changes were made. The images or other third party material in this article are included in the article's Creative Commons licence, unless indicated otherwise in a credit line to the material. If material is not included in the article's Creative Commons licence and your intended use is not permitted by statutory regulation or exceeds the permitted use, you will need to obtain permission directly from the copyright holder. To view a copy of this licence, visit http://creativecommons.org/licenses/by/4.0/ The Creative Commons Public Domain Dedication waiver (http://creativecommons.org/publicdomain/zero/1.0/) applies to the data made available in this article, unless otherwise stated in a credit line to the data. 
$\mathrm{CO}_{2}$ levels [11]. Thus, much attention has been paid to the bio-diversity of copepods in aquatic ecosystems [12, 13].

Copepods are the intermediate hosts of the parasitic nematode Dracunculus medinensis, which causes a serious Guinea-worm disease in Nigeria and elsewhere [14]. Humans could become infected by drinking unfiltered water containing copepods which are infected with larvae of $D$. medinensis. Therefore, most studies on copepods from Nigeria have focused on their role in the dispersal of the pathogen $[15,16]$. Only a few regional biogeographic studies have been conducted on copepods based on morphological species identification [17]. For example, based on the morphology, a previous study showed the occurrence of the genera Mesocyclops Sars, 1914 and Thermocyclops Kiefer, 1927 in Nigerian freshwater ecosystems: six Mesocyclops species and three Thermocyclops species were identified [18]. Moreover, it was believed that $M$. aspericornis was one of the most abundant species of Mesocyclops in Nigerian waterbodies, and $T$. decipiens was the most abundant species of Thermocyclops from Nigeria [18]. However, the identification of different species of copepods solely based on morphology has technical limitations [19], as cryptic species are often detected. Therefore, more discerning methods such as DNA barcoding are needed to investigate copepod taxonomy, especially to recognize morphologically cryptic genetic lineages [20].

DNA barcoding has already been successfully applied to estimate the species/genetic diversity in many zooplankton taxa [21], as it can be used for rapid, accurate, reliable and remote identification of specimens of all metazoan [22]. A fragment of the mitochondrial cytochrome $c$ oxidase subunit I (COI) gene has proved to be a useful marker for many biodiversity studies [23, 24], as COI has advantages of being effective for species identification from a wider range of metazoan phyla and possessing a phylogenetic signal which can be used over a wider range of taxonomic levels [22]. The COI marker has been successfully applied to species identification for cladocerans $[25,26]$. For example, DNA barcoding was used to identify sibling cryptic species of the Ceriodaphnia cornuta species complex from Australia [27] and to examine 61 species of Cladocera, such as Daphnia, Diaphanosoma, Ceriodaphnia, Moina and Alona, from Mexico and Guatemala [28]. This approach has also been applied to copepods [29]. For instance, a study reported 800 new sequences of 63 marine copepod species by using a COI marker [30]. Elías-Gutierrez et al. [28] examined 21 species of Copepoda from Mexico and Guatemala by applying a COI marker. Using COI is highly advantageous because it can also detect cryptic species, a phenomenon that is very common in copepod assemblages [31]. For example, three genetically divergent but morphologically similar forms of Hemidiaptomus (Occidodiaptomus) ingens were detected throughout the distribution range of this species complex [32]. Moreover, Oithona similis s.l. was found to be a complex of nine cryptic species instead of a single cosmopolitan species, according to a COI and a nuclear ribosomal $28 \mathrm{~S}$ genetic marker [20]. Similarly, the nominal species "Eudiaptomus hadzici" in the Western Balkans consists of four cryptic species according to a mitochondrial (COI) and a nuclear (nH3) marker [33]. DNA barcoding often reveals differences between allopatric populations. In that situation, it is difficult to decide whether this indicates different genetic lineages or simply geographical intraspecific variation. For instance, several different genetic lineages of Moina which were allopatric in a phylogeny were assigned to a single species, because they had similar morphology [34].

The phylogeny of copepods had been widely studied using molecular data. Recently, a comprehensive study from Asia showed a high species diversity of copepods in South Korea [29]. In that study, 133 sequenced individuals represented 94 species belonging to six different orders [29]. Another study has shown that Sinocalanus tenellus consists of two very distinct clades in China, suggesting they are parts of a complex of cryptic species [35]. Moreover, Karanovic [36] detected a new species of Schizopera from Japan, which was the first member of its genus reported in Japanese freshwater ecosystems, and it had no close relatives from elsewhere in the world. Another study has revised the higher systematics of copepods and proposed the new taxa Canuelloida ordo. nov., Smirnovipinidae fam. nov. and Cyclopicinidae fam. nov. [37]. Use of molecular data has not been restricted to species-level taxonomy [20], for example, the phylogeography of copepods has been also frequently investigated. They focused on the genealogical lineages of closely related species of copepods and their geographic distributions, by combining the information from phylogenetics, molecular genetics, population genetics, geology, paleontology, demography, ethology and historical biogeography [38]. For instance, two species of copepods (i.e. Neodiaptomus schmackeri and Mongolodiaptomus birulai) occur in Chinese Taiwan: there was little gene flow among populations for both species [39]. Additionally, four populations of Leptodiaptomus cf. sicilis in Mexico were found to diverge into 3 distinct phenotypes, and their specialization was further supported by molecular data which showed persistence of a founder effect, limited gene flow, and a pattern of allopatric speciation [40].

There have been no studies on phylogeography and genetic diversity of copepods from Nigeria. In this study, we analyzed 15 copepod populations (out of 32 pools/ lakes sampled) from Nigeria. By analyzing sequence variation in the COI gene, we aimed to explore the species diversity and distribution of copepods among these populations. Our expectation was to detect several members 
of the Cyclopidae, as it is commonly observed worldwide $[29,37]$. We also investigated the phylogeography of Cyclopidae in Nigeria.

\section{Results}

\section{Species and COI genetic diversity}

One to 9 specimens of Cyclopidae were sequenced per location, and a total of 88 Cyclopidae COI sequences were successfully obtained from 15 freshwater lakes around Southeast Nigeria, of which 18 unique haplotypes were detected (Tables 1 and 2). None of the COI sequences exhibited characteristics of nuclear pseudogenes (frame shifts or premature stop codons). Two independent species-delimitation methods (i.e. GMYC and bPTP) based on the COI Bayesian tree consistently identified 12 Cyclopidae species from Nigeria: 5 species of Tropocyclops (i.e. T. cf. confinis, T. cf. onabamiroi, T. cf. prasinus, T. cf. prasinus shagamiensis and T. cf. mellanbyi), 5 species of Mesocyclops (i.e. $M$. cf. aspericornis, $M$. cf. dussarti, M. cf. ogunnus, M. cf. aequatorialis similis and $M$. cf. salinus) and 2 species of Thermocyclops (i.e. T. decipiens and T. cf. crassus; Figs. 1 and 2). Species identified through molecular analyses fell into 2 distinct clades (i.e. clade I: $T$. cf. confinis, $T$. cf. onabamiroi, $T$. cf. prasinus, T. cf. prasinus shagamiensis and T. cf. mellanbyi; clade II: $M$. cf. aspericornis, $M$. cf. dussarti, $M$. cf. ogunnus, $M$. cf. aequatorialis similis, M. cf. salinus, $T$. decipiens and T. cf. crassus). Two Thermocyclops species were in the same clade as the Mesocyclops species. Pairwise genetic distances (uncorrected $p$-distances) based on COI sequence analysis ranged from 0.05 to 0.257 between species (Table 3). For each species, the population haplotype diversity $\left(\mathrm{H}_{\mathrm{d}}\right)$ of COI ranged from 0 to 0.533 , and the population nucleotide diversity $(\pi)$ ranged from 0 to $6.86 \times 10^{-3}$ (Table 2).

\section{Geographic distribution of species}

Based on the haplotype network, seven out of 12 species detected through analysis of the COI gene occurred at more than one locality in Nigeria (Fig. 1b). The most frequently occurring species in this study was $T$. cf. prasinus, which had 4 haplotypes and was distributed in 4 lakes, including A5G, AOR, O3M and $\mathrm{U} 1 \mathrm{H}$, and one of the 4 haplotypes was shared by 3 lakes (A5G, AOR, O3M). Such a pattern was also observed in species $M$. cf. dussarti, which had 2 haplotypes and one of them was shared by 3 lakes (N1O, $\mathrm{N} 2 \mathrm{O}$ and UBS) (Fig. 1b). Different Cyclopidae species co-existed in the same lake. For example, three species (i.e. T. cf. confinis, T. cf. prasinus and T. cf. crassus) co-existed in Lake A5G (Fig. 1b). Similarly, T. cf. onabamiroi, $M$. cf. aequatorialis similis and $M$. cf. salinus co-existed in Lake UII (Fig. 1b). Moreover, five out of 18 haplotypes were shared by different lakes (Fig. 1b). The most abundant haplotype was CTH1, including 21 specimens shared by A1G, A2G and IHE. This was followed by CMS1, shared by N1O, N2O and UBS, and CTR1, shared by A5G, AOR and O3M (Fig. 1b). Four species (i.e. T. cf. onabamiroi, T. cf. mellanbyi, $M$. cf. ogunnus and $M$. cf. aequatorialis similis) expressed only one haplotype with a single individual (Fig. 1b).

Table 1 List of localities inhabited by Cyclopidae (name, abbreviation, geographical position), sampling time and water surface temperature

\begin{tabular}{|c|c|c|c|c|}
\hline Lake (abbreviation) & Latitude & Longitude & Sampling time & Water surface temperature $\left({ }^{\circ} \mathrm{C}\right)$ \\
\hline Agu Ekwegbe Pool 1 (A1G) & $6.70^{\circ} \mathrm{N}$ & $7.52^{\circ} \mathrm{E}$ & August, 2018 & 30.3 \\
\hline Agu Ekwegbe Pool 2 (A2G) & $6.71^{\circ} \mathrm{N}$ & $7.51^{\circ} \mathrm{E}$ & August, 2018 & 30.3 \\
\hline Agu Ekwegbe Pool 5 (A5G) & $6.73^{\circ} \mathrm{N}$ & $7.50^{\circ} \mathrm{E}$ & August, 2018 & 30.7 \\
\hline Adanni Opanda Rd. Pool 1 (AOR) & $6.75^{\circ} \mathrm{N}$ & $7.02^{\circ} \mathrm{E}$ & September, 2018 & 29.2 \\
\hline Ihe (IHE) & $6.84^{\circ} \mathrm{N}$ & $7.40^{\circ} \mathrm{E}$ & August, 2018 & 29.7 \\
\hline Nome 1 (N1O) & $6.80^{\circ} \mathrm{N}$ & $7.41^{\circ} \mathrm{E}$ & August, 2018 & 24.7 \\
\hline Nome 2 (N2O) & $6.79^{\circ} \mathrm{N}$ & $7.42^{\circ} \mathrm{E}$ & August, 2018 & 23.9 \\
\hline Nike Lake (NKL) & $6.51^{\circ} \mathrm{N}$ & $7.51^{\circ} \mathrm{E}$ & August, 2018 & 29.4 \\
\hline Omasi Pool 1 (O1M) & $6.69^{\circ} \mathrm{N}$ & $6.99^{\circ} \mathrm{E}$ & September, 2018 & 30.6 \\
\hline Omasi Pool 3 (O3M) & $6.70^{\circ} \mathrm{N}$ & $6.98^{\circ} \mathrm{E}$ & September, 2018 & 29.8 \\
\hline Ogele Ube Lake Opi (OUL) & $6.76^{\circ} \mathrm{N}$ & $7.49^{\circ} \mathrm{E}$ & August, 2018 & 31.1 \\
\hline Uhele Pool Opi (U1H) & $6.75^{\circ} \mathrm{N}$ & $7.48^{\circ} \mathrm{E}$ & August, 2018 & 29.6 \\
\hline Ukwuado Pool 2 Opi (U2P) & $6.74^{\circ} \mathrm{N}$ & $7.49^{\circ} \mathrm{E}$ & August, 2018 & 30.3 \\
\hline Ukwuado Bus Stop Opi Lake (UBS) & $6.75^{\circ} \mathrm{N}$ & $7.49^{\circ} \mathrm{E}$ & August, 2018 & 31.7 \\
\hline Ushuiyi Isusu Ihandiagu (UII) & $6.82^{\circ} \mathrm{N}$ & $7.58^{\circ} \mathrm{E}$ & August, 2018 & 25.9 \\
\hline
\end{tabular}


Table 2 Genetic characterization of sequenced individuals of Cyclopidae in each population

\begin{tabular}{|c|c|c|c|c|c|c|c|c|}
\hline \multirow[t]{2}{*}{ Lake (abbreviation) } & \multicolumn{7}{|c|}{ Mitochondrial gene (COI) } & \multirow[t]{2}{*}{ Species } \\
\hline & $\mathrm{N}_{1}$ & $\mathrm{~N}_{2}$ & Haplotype & $\mathrm{H}_{\mathrm{d}}$ & stdev of $\mathrm{H}_{\mathrm{d}}$ & $\pi$ & stdev of $\pi$ & \\
\hline Agu Ekwegbe Pool 1 (A1G) & 9 & 1 & $\mathrm{CTH} 1$ & 0.00 & 0.00 & 0.00 & 0.00 & Thermocyclops decipiens \\
\hline Agu Ekwegbe Pool 2 (A2G) & 6 & 1 & $\mathrm{CTH} 1$ & 0.00 & 0.00 & 0.00 & 0.00 & Thermocyclops decipiens \\
\hline \multirow[t]{3}{*}{ Agu Ekwegbe Pool 5 (A5G) } & 1 & 1 & A5G1 & n.s & n.s & n.s & n.s & Tropocyclops cf. confinis \\
\hline & 3 & 1 & $\mathrm{CTH} 2$ & 0.00 & 0.00 & 0.00 & 0.00 & Thermocyclops cf. crassus \\
\hline & 1 & 1 & CTR1 & n.s & n.s & n.s & n.s & Tropocyclops cf. prasinus \\
\hline Adanni Opanda Rd. Pool 1 (AOR) & 7 & 1 & CTR1 & 0.00 & 0.00 & 0.00 & 0.00 & Tropocyclops cf. prasinus \\
\hline Ihe (IHE) & 6 & 1 & $\mathrm{CTH} 1$ & 0.00 & 0.00 & 0.00 & 0.00 & Thermocyclops decipiens \\
\hline Nome 1 (N1O) & 8 & 2 & N1O1, CMS1 & 0.429 & 0.169 & $7.9 \times 10^{-4}$ & $3.1 \times 10^{-4}$ & Mesocyclops cf. dussarti \\
\hline Nome 2 (N2O) & 7 & 1 & CMS1 & 0.00 & 0.00 & 0.00 & 0.00 & Mesocyclops cf. dussarti \\
\hline \multirow[t]{2}{*}{ Nike Lake (NKL) } & 1 & 1 & NKL1 & n.s & n.s & n.s & n.s & Mesocyclops cf. ogunnus \\
\hline & 1 & 1 & NKL2 & n.s & n.s & n.s & n.s & Tropocyclops cf. mellanbyi \\
\hline Omasi Pool 1 (O1M) & 1 & 1 & $\mathrm{CTH} 2$ & n.s & n.s & n.s & n.s & Thermocyclops cf. crassus \\
\hline \multirow[t]{2}{*}{ Omasi Pool 3 (O3M) } & 1 & 1 & $\mathrm{CTH} 2$ & n.s & n.s & n.s & n.s & Thermocyclops cf. crassus \\
\hline & 6 & 2 & CTR1, O3M1 & 0.533 & 0.172 & $9.8 \times 10^{-4}$ & $3.2 \times 10^{-4}$ & Tropocyclops cf. prasinus \\
\hline \multirow[t]{2}{*}{ Ogele Ube Lake Opi (OUL) } & 6 & 1 & OUL1 & 0.00 & 0.00 & 0.00 & 0.00 & Mesocyclops cf. aspericornis \\
\hline & 1 & 1 & OUL2 & n.s & n.s & n.s & n.s & Mesocyclops cf. salinus \\
\hline \multirow[t]{2}{*}{ Uhele Pool Opi (U1H) } & 6 & 2 & $\mathrm{U} 1 \mathrm{H} 1, \mathrm{U} 1 \mathrm{H} 2$ & 0.533 & 0.172 & $6.86 \times 10^{-3}$ & $2.21 \times 10^{-3}$ & Tropocyclops cf. prasinus \\
\hline & 2 & 1 & CTR2 & 0.00 & 0.00 & 0.00 & 0.00 & Tropocyclops cf. prasinus shagamiensis \\
\hline \multirow[t]{2}{*}{ Ukwuado Pool 2 Opi (U2P) } & 1 & 1 & CTR2 & n.s & n.s & n.s & n.s & Tropocyclops cf. prasinus shagamiensis \\
\hline & 1 & 1 & U2P1 & n.s & n.s & n.s & n.s & Tropocyclops cf. confinis \\
\hline Ukwuado Bus Stop Opi Lake (UBS) & 8 & 1 & CMS1 & 0.00 & 0.00 & 0.00 & 0.00 & Mesocyclops cf. dussarti \\
\hline \multirow[t]{3}{*}{ Ushuiyi Isusu Ihandiagu (UII) } & 1 & 1 & UII1 & n.s & n.s & n.s & n.s & Mesocyclops cf. aequatorialis similis \\
\hline & 3 & 1 & UII2 & 0.00 & 0.00 & 0.00 & 0.00 & Mesocyclops cf. salinus \\
\hline & 1 & 1 & UII3 & n.s & n.s & n.s & n.s & Tropocyclops cf. onabamiroi \\
\hline
\end{tabular}

$\mathrm{N}_{1}$ is the number of individuals used for COI sequencing, $\mathrm{N}_{2}$ is the number of haplotypes, $\mathrm{H}_{d}$ is haplotype diversity, stdev of $\mathrm{H}_{d}$ is standard deviation of haplotype diversity, $\pi$ is nucleotide diversity, stdev of $\pi$ is standard deviation of nucleotide diversity

\section{Discussion}

Through analysis of COI sequence variation, we explored the species diversity and distribution of copepods within the family Cyclopidae for 15 Nigerian freshwater ecosystems, the first such study for West Africa. Our results suggested a high species diversity of Cyclopidae copepods over a small geographic sampling range.

High species diversity has already been reported in the copepods from Nigeria [18, 19]. Forty species of Cyclopidae copepods from Nigeria were described based on morphological characteristics in the 1990s [19]. Here, we did not detect any new species based on molecular data; all the 12 species identified in the present study were described in [19]. In agreement with a previous study based on morphology [18], we found that $T$. decipiens was the most abundant species of Thermocyclops from Nigeria. However, M. aspericornis was recorded as the most abundant species of Mesocyclops in Nigerian waterbodies [18], whereas we found that $M$. cf. dussarti is the most abundant species of the genus Mesocyclops. This inconsistency might be explained by the relatively small sampling region in our study in Southeast Nigeria.

Globally, high levels of species diversity of copepods have also been reported $[29,41]$. For example, 53 Caligus species were present in Chinese Taiwan, and many more species remained to be discovered from this region [5]. Similarly, thirteen species of Copepoda, including three members of Calanoida (Diaptomidae) and ten members of Cyclopoida (Eucyclopinae and Cyclopinae), were recorded in Chiapas, Mexico [42]. Indeed, high species diversity, even in a relatively small area, has often been observed in copepods [41, 43, 44]. For example, a study identified 43 species that belonged to 11 genera of copepods in Sagami Bay [43]. Another study identified 48 species of copepods in Tolo Harbour, Hong Kong, and Oithona rigida, O. simplex and Paracalanus crassirostris were found to be the most abundant species [44]. Here, we detected 12 species with several species and 


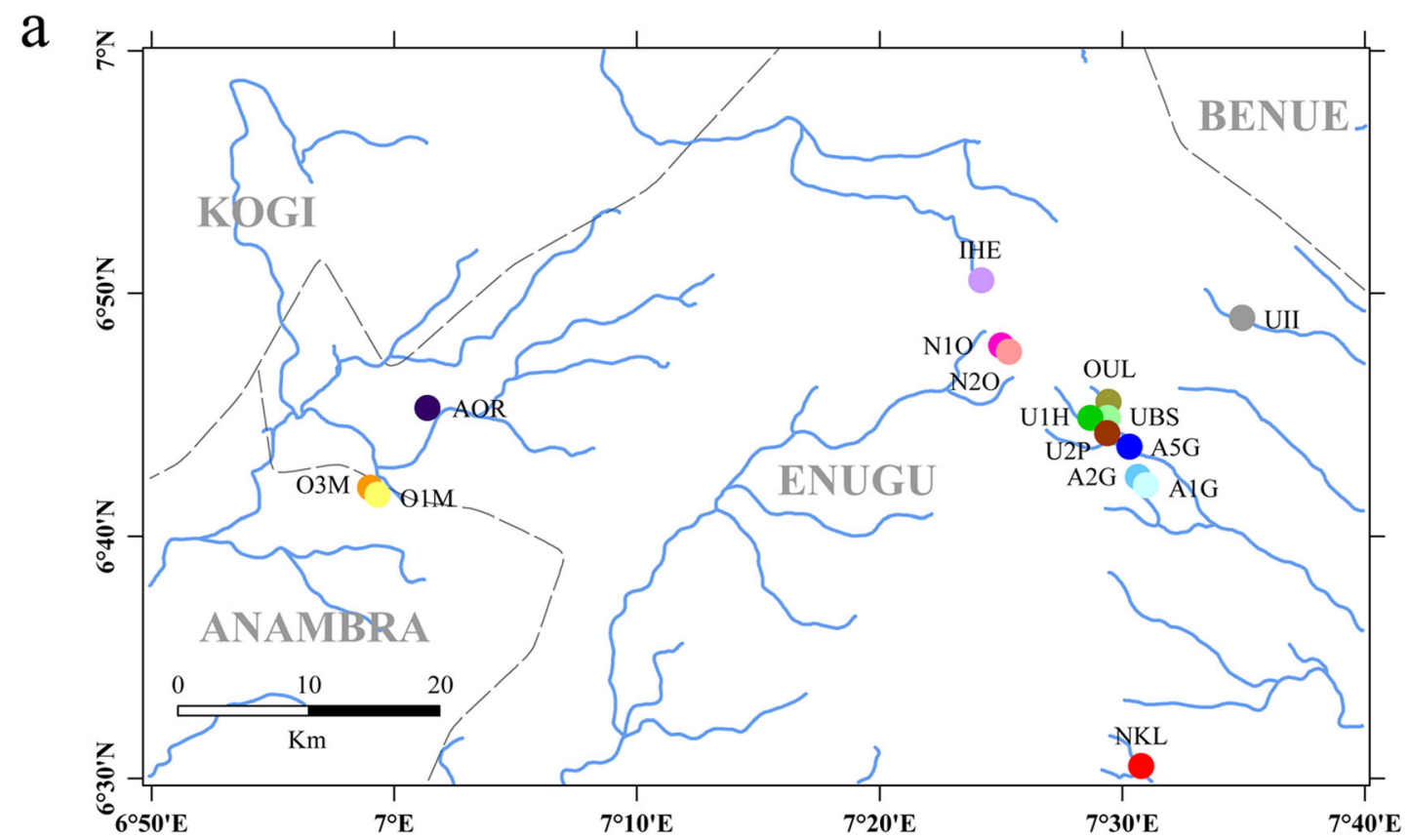

b

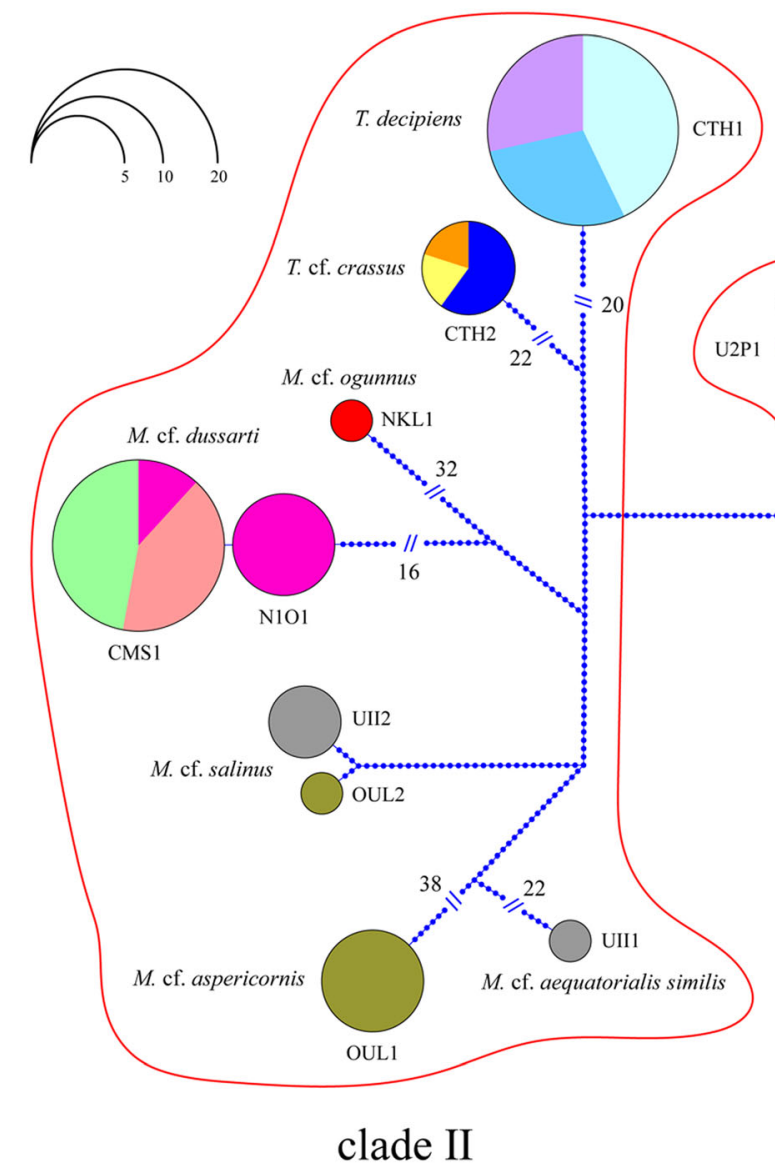

Fig. 1 (See legend on next page.) 
(See figure on previous page.)

Fig. 1 a Geographic locations of sampling sites for Cyclopidae in Nigeria. b Haplotype network of Cyclopidae from Nigeria, based on the COI gene (544 bp). Each circle represents a unique haplotype and its size reflects the number of individuals expressing that haplotype. Color codes denote geographic location of populations. Portion of circles indicate distribution of haplotypes among different populations. The number of marks on connecting lines indicates the number of mutations between haplotypes. For lake abbreviations see Table 1. The map was obtained from ArcGIS and edited in Adobe Illustrator

species complexes across three genera in Nigeria; suggesting a high species diversity of Cyclopidae in Southeast Nigeria.

In agreement with a previous study of Cyclopoida in Nigeria [18], our results showed that the same species could be found in geographically separate populations, which also suggests that there are not extensive and common cryptic species in these sampled lakes. Thermocyclops decipiens has also been detected in Antilles, Central America, Columbia, Venezuela, east of the Andes, Brazil [45] and Congo [46], indicating that this species has a wide distribution across continents. In contrast to several copepod species with high genetic divergence over short distances, e.g. Tigriopus californicus [47], our data showed genetic similarity of the $T$. decipiens populations from different continents. A similar phenomenon has been detected in some open-ocean copepods which have more obvious dispersal routes. For example, it was found that several mtCOI haplotypes of Calanus pacificus were distributed across multiple sampling location from the North Pacific Ocean [48]. By using restriction site-associated DNA sequencing, no significant genetic differentiation was found among Centropages typicus samples collected from different NW Atlantic regions with clear connectivity [49]. Zooplankton species often have vast ranges [34, 50]. For example, Daphnia galeata has been detected in both China and Europe with some haplotypes shared across large distances [51]. Birds are often regarded as the key vectors for the dispersal of resting eggs of aquatic zooplankton [52], across geographical barriers.

We found that different sibling species of Cyclopidae co-existed in the same Nigerian lake, a common finding in copepods [29]. For example, a study of the genus Mesocyclops conducted in Africa reported that M. major and $M$. ogunnus often co-existed in the same waterbody [53]. Similarly, another study from Nigeria reported that

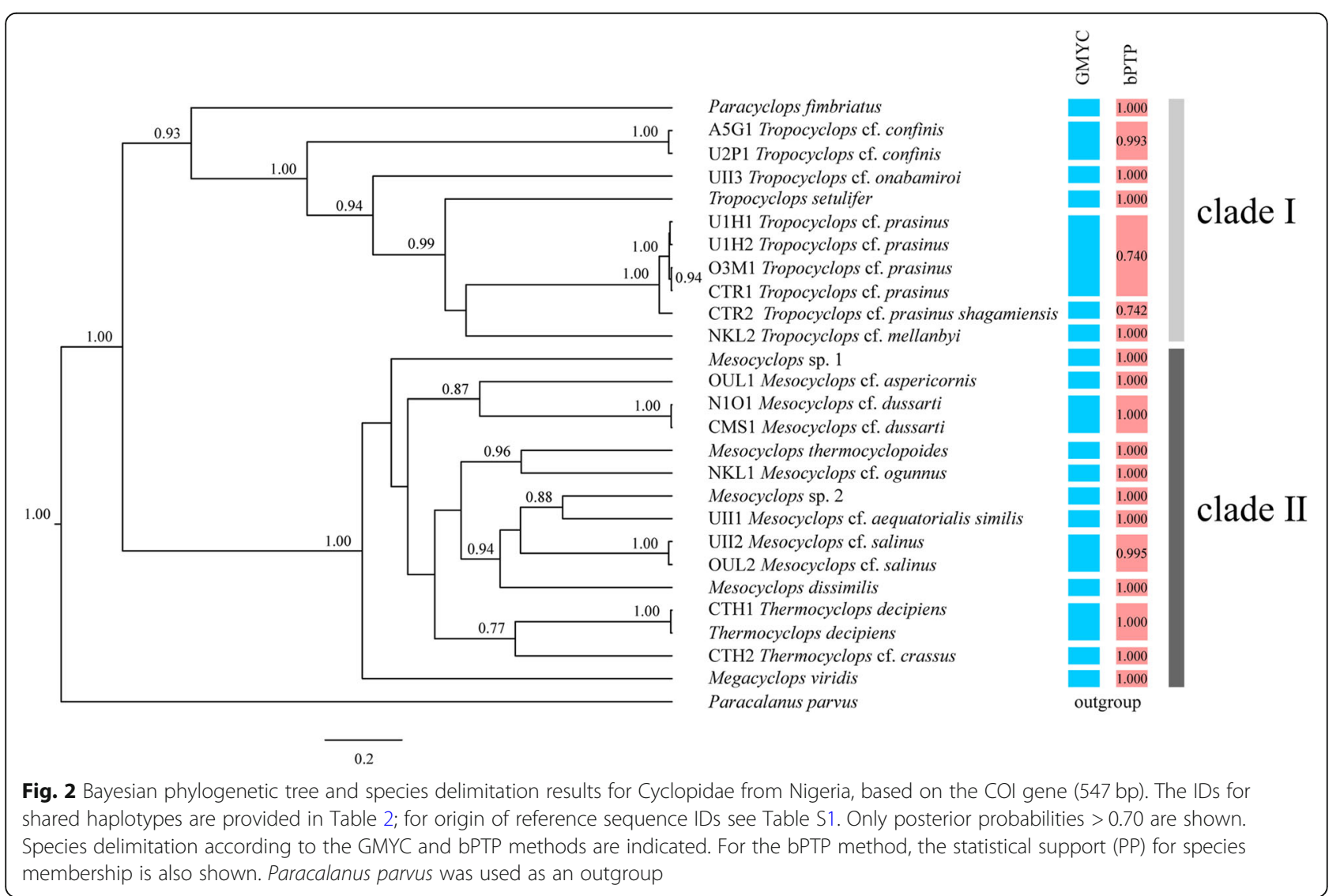




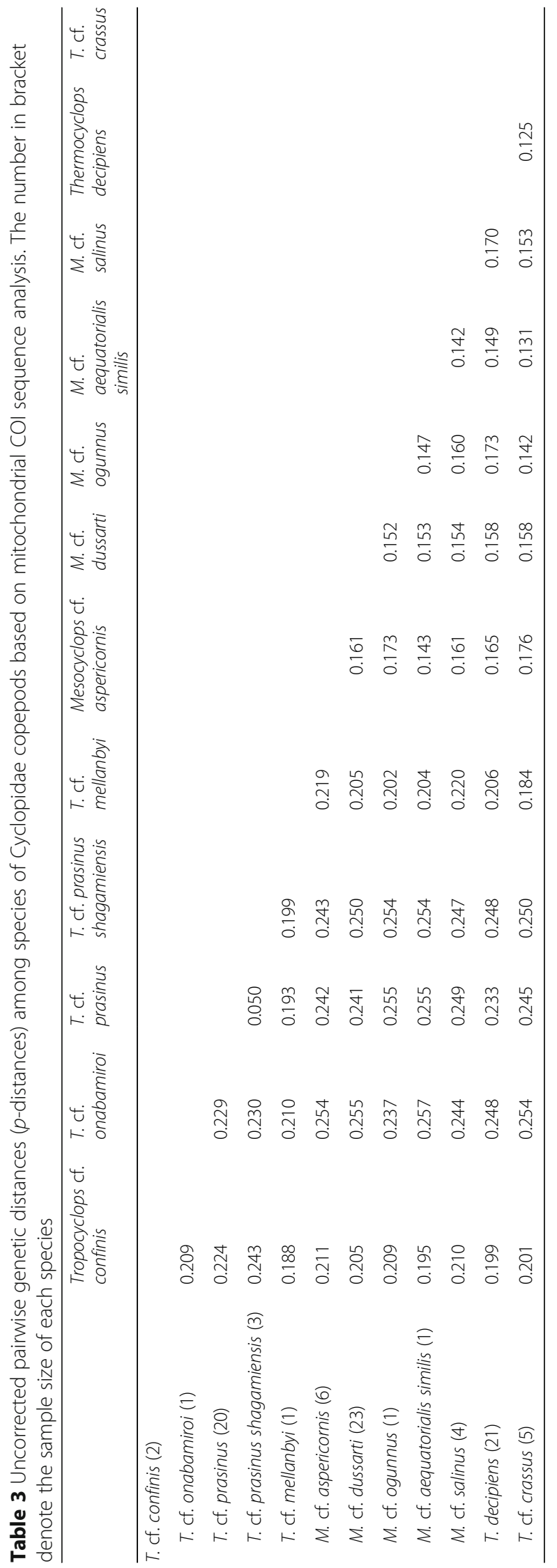


it was common for up to 3 Mesocyclops species coexisted in a single locality [18]. Sympatry provides a possibility for interspecific hybridization, which is believed to be a common phenomenon in zooplankton [54]. Hybridization has often been observed in copepods. For example, hybrids between Calanus glacialis and C. finmarchicus were detected along the Atlantic and Arctic Canadian coast [55]. Another study also found that hybridization occurred between a female Neocalanus cristatus and a male N. plumchrus, and was then followed by backcrossing to a $N$. plumchrus individual [56]. Our molecular data indicated paraphyly between Thermocyclops and Mesocyclops, which might reflect introgression resulting from hybridization [57]. Paraphyly has also been observed in other zooplankton, for example, in the Daphnia pulex species complex [58] and Moina [34]. Future studies and nuclear markers are needed to investigate gene introgression among the copepod species from Nigeria.

Here, Cyclopidae in Nigeria showed a high species diversity, but for each species, the haplotype diversity and nucleotide diversity were rather low. Consistently, low haplotype and nucleotide diversities were observed in the copepods Calanus finmarchicus [59], C. agulhensis and C. sinicus [60]. Patterns of population genetic diversity could be caused by different evolutionary forces, such as mutation, migration, genetic drift and natural selection. How these evolutionary forces affect the population genetic diversity depends on many factors, including species' response to environmental changes, and the past and present sizes of the population [59]. Another explanation might be that the structuring of a metapopulation together with founder effects resulted in low population genetic diversity [61, 62]. However, the limited sampling of each species among populations cannot be ruled out as a cause for their low genetic diversity in this study.

\section{Conclusions}

In conclusion, our data revealed a high species diversity of Cyclopidae in Southeast Nigeria: twelve species were detected. Our geographical sampling scale in this study was quite small, and therefore, further studies are called for a comprehensive understanding of species distribution and genetic diversity of Cyclopidae in West Africa.

\section{Methods}

\section{Sampling}

Copepod specimens were collected from 15 freshwater lakes around Southeast Nigeria (Fig. 1a and Table 1). Samples were collected using a $125-\mu \mathrm{m}$ plankton net hauled vertically through the water column at three different sites per location. Samples collected from different sites in the same location were pooled together and preserved in 95\% ethanol. All specimens were identified morphologically according to the morphological description of copepods in Nigeria [17-19, 63], which also worked as taxonomic keys in this paper.

\section{DNA extraction, PCR amplification and sequencing}

Copepods were processed for molecular analyses (Table 2). The cephalosome portion of the prosome was obtained from each individual copepod to avoid DNA contamination from prey items in the gut, using a microscopic tweezer and a sharp blade under the stereomicroscope. Total genomic DNA was extracted from the head using $\mathrm{H} 3$ buffer with proteinase $\mathrm{K}(30 \mu \mathrm{L})$, containing $10 \mathrm{mM}$ Tris- $\mathrm{HCl}, 0.05 \mathrm{M} \mathrm{KCl}, 0.005 \%$ Tween 20 , $0.005 \% \mathrm{NP}-40$ and $10 \mathrm{mg} / \mathrm{ml}$ proteinase $\mathrm{K}$ (MERCK, Germany). Samples were incubated overnight at $55^{\circ} \mathrm{C}$ in a water-bath with mild shaking. The proteinase $\mathrm{K}$ was irreversibly denatured after a 12 -min incubation at $95^{\circ} \mathrm{C}$. The homogenate was centrifuged briefly and stored at $4{ }^{\circ} \mathrm{C}$ before use. A 680 base-pair fragment of the COI gene was amplified using the consensus primer pair (forward: 5' - GGT CAA CAA ATC ATA AAG ATA TTG G-3'; reverse: 5' - TAA ACT TCA GGG TGA CCA AAA AAT CA -3' [64];). Polymerase chain reaction (PCR) was carried out in a total volume of $20 \mu \mathrm{L}$, consisting of $2 \mu \mathrm{L} 10 \mathrm{X}$ PCR buffer $(10 \mathrm{mM}$ Tris- $\mathrm{HCl}, \mathrm{pH}$ 8.3, $\left.5 \mathrm{mM} \mathrm{MgCl}_{2}, 50 \mathrm{mM} \mathrm{KCl}\right), 2 \mu \mathrm{L} 2.5 \mathrm{mM}$ of each dNTP, $1 \mu \mathrm{L} 0.5 \mu \mathrm{M}$ of each primer, $11.6 \mu \mathrm{L}$ water, 2 units of Taq DNA polymerase (SuperTherm DNA polymerase, Taq HS from TAKARA BIO INC., California, USA) and $2 \mu \mathrm{L}$ of genomic DNA. The PCR thermocycle protocol was as follows: denaturation at $94{ }^{\circ} \mathrm{C}$ for $1 \mathrm{~min}$, then 40 cycles of $1 \mathrm{~min}$ at $94{ }^{\circ} \mathrm{C}, 1.5 \mathrm{~min}$ at $40^{\circ} \mathrm{C}$ and $1.5 \mathrm{~min}$ at $72^{\circ} \mathrm{C}$; followed by a final elongation at $72^{\circ} \mathrm{C}$ for $6 \mathrm{~min}$. The success of amplification was checked using agarose gel electrophoresis. Afterwards, the PCR products were purified (High Pure PCR Product Purification Kit, Roche Diagnostics) and sequenced in the forward direction on an ABI PRISM 3730 DNA capillary sequencer by Invitrogen Trading Co., Ltd. (China). Chromatograms were checked for ambiguous base calling and errors in base calling were corrected using MEGA 6 [65], and the Phred quality scores of the sequences were examined with Chromas Lite Version 2.1 (Technelysium Pty. Ltd., South Brisbane, Australia). Sequences with double peaks or noise were re-sequenced in the reverse direction, and only chromatograms of high quality were applied to the following genetic analyses. All newly obtained sequences were submitted to GenBank under accession numbers MN990471-MN990488.

\section{Sequence alignment and genetic diversity}

We identified unique haplotypes in DnaSP 5.10 [66]. MUSCLE [67] implemented in MEGA 6 was used to 
align the sequences that were subsequently translated into amino acids to examine the presence of stop codons. Afterwards, all haplotypes were aligned, together with 8 reference sequences obtained from GenBank (Table S1), using the Clustal W algorithm [68] in MEGA 6. Then, all the sequences were timed to a uniform length of $544 \mathrm{bp}$ in MEGA 6 . For each species, the number of haplotypes $\left(\mathrm{N}_{2}\right)$, haplotype diversity $\left(\mathrm{H}_{\mathrm{d}}\right)$ and nucleotide diversity $(\pi)$ per population (populations with sample size less than 3 were excluded) were calculated in DnaSP 5.10.

\section{Phylogenetic analyses}

The test of Xia et al. [69] implemented in DAMBE 5 [70] was used to inspect potential loss of phylogenetic signal resulting from substitution saturation at the COI locus. A phylogenetic tree was then constructed using the Bayesian method in BEAST 2 [71], with a tree sampled every 1000 generations among 10,000, 000 , a burn-in of $25 \%$, and the final 10,000 trees summarized using TreeAnnotator. The best-fitting substitution model was GTR $+\mathrm{G}+\mathrm{I}$ according to the corrected Akaike Information Criterion in jModeltest v. 2.1.7 [72]. We applied a strict molecular clock and set other tree priors to their default values. Tracer v1.6 [73] was applied to ensure that enough generations were computed. Paracalanus parvus, a member of the Calanoida phylogenetically close to Cyclopoida, was used as an outgroup.

\section{Species identification and phylogeographic analyses}

To test the hypothesis that the Cyclopidae in Nigeria contains high biodiversity, two independent species delimitation methods were applied: the general mixed Yule coalescent model (GMYC [74]) and Poisson tree processes methods (PTP [75]). The GMYC model is a likelihoodbased method using an ultrametric tree to delimit species by fitting within- and between-species branching models to reconstruct gene trees. We performed the GMYC modeling using the "splits" package [76] in R 2.15 [77] and conducted the PTP calculations on the bPTP webserver (http://species.h-its.org/ptp/), with 100,000 Markov Chain Monte Carlo (MCMC) generations, thinning set to 100 , burnin at $25 \%$ and a Bayesian search performed. The input phylogenetic tree was generated using BEAST 2 (see above). A network of COI haplotypes was then constructed to visualize genetic relationships among populations using Haploviewer [78]. The maximum likelihood tree inferred with MEGA 6 using the best model GTR + G + I (by jModeltest v. 2.1.7) was applied as input. Uncorrected pairwise genetic distances between species were calculated in MEGA 6 based on COI.

\section{Supplementary information}

Supplementary information accompanies this paper at https://doi.org/10. 1186/s12862-020-01608-5.

Additional file 1: Table S1. List of reference COI sequences of Cyclopidae (from South Korea, Brazil and China) and the outgroup used in this study.

\section{Abbreviations}

COI: Mitochondrial cytochrome c oxidase subunit I gene; PCR: Polymerase chain reaction; bp: Base pairs; GMYC: The general mixed Yule coalescent model; PTP: Poisson tree processes methods

\section{Acknowledgements}

We thank David Blair for critical discussion and the linguistic help, and the anonymous reviewer for useful comments on the earlier version of this manuscript.

\section{Authors' contributions}

MY designed the study, CE, EO, CO, FA, CN, JO and PU collected samples, YN and JW carried out the molecular work. YN, WH and MY contributed to data analyses. MY wrote the manuscript with the help of YN. All authors read and approved the final version.

\section{Funding}

This research was funded by the National Natural Science Foundation of China (31670380) and Natural Science Foundation of Shanghai (16ZR1402900) to MY. The funding bodies played no role in the design of the study and collection, analysis, and interpretation of data and in writing the manuscript.

Availability of data and materials

All the sequencing data are available via NCBI (under accession numbers MN990471-MN990488).

Ethics approval and consent to participate

Collection of zooplankton (copepods in this study) did not require specific permissions because these samples were obtained from unprotected lakes that are open for public activities. Our study did not involve the use or collection of endangered or protected species.

Consent for publication

Not applicable.

\section{Competing interests}

The authors declare that they have no competing interests.

\section{Author details}

${ }^{1}$ MOE Key Laboratory for Biodiversity Science and Ecological Engineering, School of Life Science, Fudan University, Songhu Road 2005, Shanghai, China. ${ }^{2}$ Department of Zoology and Environmental Biology, University of Nigeria, Nsukka, Enugu State 410001, Nigeria.

Received: 11 July 2019 Accepted: 31 March 2020

Published online: 21 April 2020

References

1. Boxshall GA, Halsey SH. An introduction to copepod diversity. London: Ray Society; 2004.

2. Huys R, Boxshall GA. Copepod Evolution. London: The Ray Society; 1991.

3. Roemmich D, Mcgowan J. Climatic warming and the decline of zooplankton in the California current. Science. 1995;267(5202):1324-6.

4. Schminke H. Entomology for the copepodologist. J Plankton Res. 2007;29: i149-62.

5. Ho J, Lin C, Liu W. High diversity of Caligus species (Copepoda: Siphonostomatoida: Caligidae) in Taiwanese waters. Zootaxa. 2016;4174: 114-21.

6. Humes AG. How many copepods. Hydrobiologia. 1994;293:1-7. 
7. Chivers WJ, Walne AW, Hays GC. Mismatch between marine plankton range movements and the velocity of climate change. Nat Commun. 2017:8: 14434.

8. Beaugrand G, Reid PC, Ibanez F, Lindley A, Edwards M. Reorganization of North Atlantic marine copepod biodiversity and climate. Science. 2002;296: 1692-4.

9. Costanza R, d'Arge R, de Groot R, Farber S, Grasso M, Hannon B, Limburg K, Naeem S, O'Neill R, Paruelo J, et al. The value of the world's ecosystem services and natural capital. Nature. 1997;387:253-60.

10. Pond D, Tarling G. Phase transitions of wax esters adjust buoyancy in diapausing Calanoides acutus. Limnol Oceanogr. 2011;56:1310-8.

11. Hays GC, Richardson AJ, Robinson C. Climate change and marine plankton. Trends Ecol Evol. 2005:20(6):337-44.

12. Blanco-Bercial L, Bradford-Grieve J, Bucklin A. Molecular phylogeny of the Calanoida (Crustacea: Copepoda). Mol Phylogenet Evol. 2011:59(1):103-13.

13. Bradford-Grieve JM, Boxshall GA, Ahyong ST, Ohtsuka S. Cladistic analysis of the calanoid Copepoda. Invertebr Syst. 2010;24(3):291-321.

14. Okoye S, Onwuliri C, Anosike J. A survey of predilection sites and degree of disability associated with guineaworm (Dracunculus medinensis). Int J Parasitol. 1995;25:1127-9.

15. Anosike J, Azoro V, Nwoke B, Keke R, Okere A, Oku E, Ogbulie J, Tony-Njoku $\mathrm{R}$, Okoro O, Nwosu D. Dracunculiasis in the north eastern border of Ebonyi state, south eastern Nigeria. Int J Hyg Envir Heal. 2003:206:45-51.

16. Morenikeji $\mathrm{O}$, Asiatu A. Progress in dracunculiasis eradication in Oyo state, south-West Nigeria: a case study. Afr Health Sci. 2010;10:297-301.

17. Onabamiro S. Four new species of Cyclops sensu lat. (Crustacea: Copepoda) from Nigeria. Proc Zool Soc Lond. 1952;122:253-66.

18. Jeje C. A revision of the Nigerian species of the genera Mesocyclops Sars, 1914 and Thermocyclops Kiefer, 1927 (Copepoda: Cyclopoida). Hydrobiologia. 1988;164:171-84.

19. Boxshall GA, Braide E. The freshwater cyclopoid copepods of Nigeria, with an illustrated key to all species. Bull Br Mus Nat Hist Zool. 1991:57:185-212.

20. Cornils A, Wend-Heckmann B, Held C. Global phylogeography of Oithona similis s.l. (Crustacea, Copepoda, Oithonidae) - a cosmopolitan plankton species or a complex of cryptic lineages? Mol Phylogenet Evol. 2017;107: 473-85.

21. Hebert PDN, Ratnasingham S, deWaard JR. Barcoding animal life: cytochrome $c$ oxidase subunit 1 divergences among closely related species. P Roy Soc B-Biol Sci. 2003;270:596-9.

22. Bucklin A, Steinke D, Blanco-Bercial L. DNA barcoding of marine Metazoa. Annu Rev Mar Sci. 2011;3:471-508.

23. Costa F, deWaard J, Boutillier J, Ratnasingham S, Dooh R, Hajibabaei M, Hebert PDN. Biological identifications through DNA barcodes: the case of the Crustacea. Can J Fish Aquat Sci. 2007;64:272-95.

24. Hebert PDN, Cywinska A, Ball S, deWaard JR. Biological identifications through DNA barcode. P Roy Soc B-Biol Sci. 2003;270:313-21.

25. deWaard JR, Sacherova V, Cristescu ME, Remigio EA, Crease T, Hebert PDN Probing the relationships of the branchiopod crustaceans. Mol Phylogenet Evol. 2006:39:491-502.

26. Jeffery NW, Elias-Gutierrez M, Adamowicz SJ. Species diversity and phylogeographical affinities of the Branchiopoda (Crustacea) of Churchill, Manitoba, Canada. PLOS One. 2011;6(5):e18364.

27. Sharma P, Kotov AA. Molecular approach to identify sibling species of the Ceriodaphnia cornuta complex (Cladocera: Daphniidae) from Australia with notes on the continental endemism of this group. Zootaxa. 2013;3702:79-89.

28. Elias-Gutierrez M, Jeronimo FM, Ivanova NV, Valdez-Moreno M, Hebert PDN. DNA barcodes for Cladocera and Copepoda from Mexico and Guatemala, highlights and new discoveries. Zootaxa. 2008;1839:1-42.

29. Baek SY, Jang KH, Choi EH, Ryu SH, Kim SK, Lee JH, Lim YJ, Lee J, Jun J, Kwak M, et al. DNA barcoding of metazoan zooplankton Copepods from South Korea. PLOS One. 2016:11(7):e0157307.

30. Blanco-Bercial L, Cornils A, Copley N, Bucklin A. DNA barcoding of marine copepods: assessment of analytical approaches to species identification. PLOS Curr. 2014

31. Dippenaar S, Mathibela R, Bloomer P. Cytochrome oxidase I sequences reveal possible cryptic diversity in the cosmopolitan symbiotic copepod Nesippus orientalis Heller, 1868 (Pandaridae: Siphonostomatoida) on elasmobranch hosts from the KwaZulu-Natal coast of South Africa. Exp Parasitol. 2010;125:42-50

32. Marrone F, Lo Brutto S, Hundsdoerfer AK, Arculeo M. Overlooked cryptic endemism in copepods: systematics and natural history of the calanoid subgenus Occidodiaptomus Borutzky 1991 (Copepoda, Calanoida, Diaptomidae). Mol Phylogenet Evol. 2013;66(1):190-202.

33. Previsic A, Gelemanovic A, Urbanic G, Ternjej I. Cryptic diversity in the Western Balkan endemic copepod: four species in one? Mol Phylogenet Evol. 2016;100:124-34

34. Ni YJ, Ma XL, Hu W, Blair D, Yin MB. New lineages and old species: lineage diversity and regional distribution of Moina (Crustacea: Cladocera) in China. Mol Phylogenet Evol. 2019;134:87-98.

35. Wang $X Y, M a X L, H u$ W, Yin MB. Genetic diversity and population differentiation of the freshwater copepod Sinocalanus tenellus (Calanoida, Centropagidae) in China. J Limnol. 2018;77(2):300-7.

36. Karanovic T, Kim K, Grygier M. A new species of Schizopera (Copepoda: Harpacticoida) from Japan, its phylogeny based on the mtCOI gene and comments on the genus Schizoperopsis. J Nat Hist. 2015;49:2493-526.

37. Khodami S, McArthur J, Blanco-Bercial L, Arbizu P. Molecular phylogeny and revision of copepod orders (Crustacea: Copepoda). Sci Rep. 2017;7:9164.

38. Avise J. Phylogeography: The History and Formation of Species. Cambridge: Harvard University Press; 2000.

39. Young S, Lin S, Liu M. Genetic diversity and population structure of two freshwater copepods (Copepoda: Diaptomidae), Neodiaptomus schmackeri (Poppe and Richard, 1892) and Mongolodiaptomus birulai (Rylov, 1922) from Taiwan. Diversity. 2013;5:796-810.

40. Barrera-Moreno O, Ciros-Perez J, Ortega-Mayagoitia E, Alcantara-Rodriquez J, Piedra-Ibarra E. From local adaptation to ecological speciation in copepod populations from neighboring lakes. PLoS One. 2015;10:e0125524.

41. Brancelj A. Microdistribution and high diversity of Copepoda (Crustacea) in a small cave in Central Slovenia. Hydrobiologia. 2002;477:59-72.

42. Gutierrez-Aguirre M, Cervantes-Mrtinez A. Diversity of freshwater copepods (Maxillopoda: Copepoda: Calanoida, Cyclopoida) from Chiapas, Mexico with a description of Mastigodiaptomus suarezmoralesi sp. nov. J Nat Hist. 2013; 47:479-98.

43. Nishida S, Kuriyama M. Species diversity and niche-partitioning in the pelagic copepods of the family Scolecitrichidae (Calanoida). Crustaceana. 2006;79:293-317.

44. Wong C, Chan A, Chen Q. Planktonic copepods of Tolo harbour, Hong Kong. Crustaceana. 1993;64:76-84.

45. Landa G, Barbosa F, Rietzler A, Barbosa P. Thermocyclops decipiens (Kiefer, 1929) (Copepoda, Cyclopoida) as indicator of water quality in the state of Minas Gerais, Brazil. Braz Arch Biol Techn. 2007;50:695-705.

46. Mirabdullayev I, Reid J, Ueda H. Copepoda: Cyclopoida genera Mesocyclops and Thermocyclops. Genus Thermocyclops Kiefer, 1927. In: Guides to the identification of the microinvertebrates of the continental waters of the world. Leiden: Backhuys Publishers; 2003. p. 214-302.

47. Willett C, Ladner JT. Investigations of fine-scale phylogeography in Tigriopus californicus reveal historical patterns of population divergence. BMC Evol Biol. 2009;9:139.

48. Nuwer M, Frost B, Armbrust V. Population structure of the planktonic copepod Calanus pacificus in the North Pacific Ocean. Mar Biol. 2008;156:107-15.

49. Blanco-Bercial L, Bucklin A. New view of population genetics of zooplankton: RADseq analysis reveals population structure of the North Atlantic planktonic copepod Centropages typicus. Mol Ecol. 2016;25:1566-80.

50. Ma X, Petrusek A, Wolinska J, Hu W, Yin M. Lineage diversity and reproductive modes of the Daphnia pulex group in Chinese lakes and reservoirs. Mol Phylogenet Evol. 2019;130:424-33.

51. Yin M, Wang X, Ma X, Giessler S, Petrusek A, Griebel J, Hu W, Wolinska J. Cytonuclear diversity and shared mitochondrial haplotypes among Daphnia galeata populations separated by seven thousand kilometres. BMC Evol Biol. 2018;18:130.

52. Green AJ, Figuerola J. Recent advances in the study of long-distance dispersal of aquatic invertebrates via birds. Divers Distrib. 2005;11(2):149-56.

53. Van de Velde I. Revision of the African species of the genus Mesocyclops Sars, 1914 (Copepoda: Cyclopidae). Hydrobiologia. 1984;109:3-66.

54. Hebert PDN. Interspecific hybridization between cyclic parthenogens. Evolution. 1985;39:216-20.

55. Parent GJ, Plourde S, Joly P, Turgeon J. Phenology and fitness of Calanus glacialis, C. finmarchicus (Copepoda), and their hybrids in the St. Lawrence estuary. Mar Ecol Prog Ser. 2015;524:1-9.

56. Machida RJ, Lin Y. Occurrence of mitochondrial CO1 pseudogenes in Neocalanus plumchrus (Crustacea: Copepoda): hybridization indicated by recombined nuclear mitochondrial pseudogenes. PLoS One. 2017;12: e0172710. 
57. Funk DJ, Omland KE. Species-level paraphyly and polyphyly: frequency, causes, and consequences, with insights from animal mitochondrial DNA. Annu Rev Ecol Evol S. 2003;34:397-423.

58. Colbourne JK, Crease TJ, Weider L, Hebert PDN, Dufresne F, Hobaek A. Phylogenetics and evolution of a circumarctic species complex (Cladocera : Daphnia pulex). Biol J Linn Soc. 1998;65(3):347-65.

59. Bucklin A, Wiebe PH. Low mitochondrial diversity and small effective population sizes of the copepods Calanus finmarchicus and Nannocalanus minor: possible impact of climatic variation during recent glaciation. J Hered. 1998;89(5):383-92.

60. Kozol R, Blanco-Bercial L, Bucklin A. Multi-gene analysis reveals a lack of genetic divergence between Calanus agulhensis and C. sinicus (Copepoda; Calanoida). PLOS One. 2012;7:e45710.

61. Hanski I, Gaggiotti O. Ecology, genetics, and evolution of metapopulations. Amsterdam: Elsevier Academic Press; 2004

62. Pannell J, Charlesworth B. Neutral genetic diversity in a metapopulation with recurrent local extinction and recolonization. Evolution. 1999;53:664-76.

63. Onabamiro S. Some new species of Cyclops sensu lat (Crustacea: Copepoda) from Nigeria. Zool J Linn Soc-Lond. 1957;43:123-33.

64. Folmer O, Black M, Hoeh W, Lutz R, Vrijenhoek R. DNA primers for amplification of mitochondrial cytochrome $c$ oxidase subunit I from diverse metazoan invertebrates. Mol Mar Biol Biotechnol. 1994:3(5):294-9.

65. Tamura K, Stecher G, Peterson D, Filipski A, Kumar S. MEGA6: molecular evolutionary genetics analysis version 6.0. Mol Biol Evol. 2013;30(12):2725-9.

66. Librado P, Rozas J. DnaSP v5: a software for comprehensive analysis of DNA polymorphism data. Bioinformatics. 2009;25(11):1451-2.

67. Edgar RC. MUSCLE: multiple sequence alignment with high accuracy and high throughput. Nucleic Acids Res. 2004;32(5):1792-7.

68. Thompson JD, Higgins DG, Gibson TJ. CLUSTAL W: improving the sensitivity of progressive multiple sequence alignment through sequence weighting, position-specific gap penalties and weight matrix choice. Nucleic Acids Res. 1994;22(22):4673-80

69. Xia XH, Xie Z, Salemi M, Chen L, Wang Y. An index of substitution saturation and its application. Mol Phylogenet Evol. 2003;26(1):1-7.

70. Xia XH. DAMBE5: a comprehensive software package for data analysis in molecular biology and evolution. Mol Biol Evol. 2013;30(7):1720-8.

71. Bouckaert R, Heled J, Kuhnert D, Vaughan T, Wu CH, Xie D, Suchard MA, Rambaut A, Drummond AJ. BEAST 2: a software platform for Bayesian evolutionary analysis. PLOS Comput Biol. 2014;10(4):e1003537.

72. Darriba D, Taboada GL, Doallo R, Posada D. jModelTest 2: more models, new heuristics and parallel computing. Nat Methods. 2012;9(8):772.

73. Rambaut A, Drummond A, Xie D, Baele G, Suchard M. Posterior summarization in Bayesian phylogenetics using Tracer 1.7. Syst Biol. 2018; 67(5):901-4.

74. Pons J, Barraclough TG, Gomez-Zurita J, Cardoso A, Duran DP, Hazell S, Kamoun S, Sumlin WD, Vogler AP. Sequence-based species delimitation for the DNA taxonomy of undescribed insects. Syst Biol. 2006;55(4):595-609.

75. Zhang JJ, Kapli P, Pavlidis P, Stamatakis A. A general species delimitation method with applications to phylogenetic placements. Bioinformatics. 2013; 29(22):2869-76.

76. Ezard T, Fujisawa T, Barraclough T. Splits: SPecies' LImits by threshold statistics R package; 2009.

77. R Development Core Team: R: A Language and Environment for Statistical Computing. R Foundation for Statistical Computing, Vienna, Austria. 2009.

78. Walter S, Ewing G, von Haeseler A. The performance of phylogenetic algorithms in estimating haplotype genealogies with migration. Mol Ecol. 2011;20:1952-63.

\section{Publisher's Note}

Springer Nature remains neutral with regard to jurisdictional claims in published maps and institutional affiliations.

Ready to submit your research? Choose BMC and benefit from:

- fast, convenient online submission

- thorough peer review by experienced researchers in your field

- rapid publication on acceptance

- support for research data, including large and complex data types

- gold Open Access which fosters wider collaboration and increased citations

- maximum visibility for your research: over $100 \mathrm{M}$ website views per year

At BMC, research is always in progress.

Learn more biomedcentral.com/submissions 